\title{
PRODUCTION OF FIRE BLIGHT- RESISTANT PEAR ROOTSTOCKS BY USING TISSUE CULTURE TECHNIQUE
}

(Received : 22.12. 2013)

\author{
By \\ N. A. Awd, H. A. Shaheen " and R. M. Abd-El-Aziz* \\ Fruit and Ornamental Breeding Department, Horticulture Research Institute, and ${ }^{*}$ Plant Bacterial \\ Disease Department, Plant Pathology Research Institute, Agriculture Research Center, Giza, Egypt.
}

\begin{abstract}
Tissue culture technique was adopted to produce pear rootstocks resistant to Erwinia amylovora, the causal organism of fire blight disease. Two streptomycin resistant and two sensitive isolates were used to infect pear callus (Pyrus communis var. betulifolia) under laboratory conditions, and the resulting resistant rootstock in pot experiments. There were differences between callus survival (resistance) and regenerated plantlets following infection with the local isolates No.2, 4 and 40. The highest value of callus survival and vegetative growth characteristics were recognized on plantlets obtained from callus infected with the isolate No.40, compared to that infected by others. Meanwhile, no regenerated plantlets were gained from calluses infected by isolate No. 80. There were differences in the number of regenerated plants depending on the regeneration hormones in the media used. The $\mathrm{GA}_{3}(1.5 \mathrm{mg} / \mathrm{l})+2 \mathrm{ip}$ $(1.5 \mathrm{mg} / \mathrm{l})$ revealed the highest number of regenerated plants. However, no regenerated plants resulted from $\mathrm{GA}_{3}(0.5 \mathrm{mg} / \mathrm{l})+\mathrm{IAA}(1.5 \mathrm{mg} / \mathrm{l})$. After acclimatization, the youngest leaves in potted plants were inoculated with bacterial isolates to evaluate plant resistance for E. amylovora. There were differences between pathogenicity of the bacterial isolates on acclimatized plants, where the isolate No.40 showed no disease syndromes. It can be concluded that the tissue culture technique can be used in producing pear rootstocks resistant against fire blight disease, and also to produce plants resistant to streptomycinresistant isolates of E. amylovora; to avoid deleterious effect of streptomycin.
\end{abstract}

Key words: fire blight, resistant callus, resistant isolates, rootstock, streptomycin-sensitive isolates.

\section{INTRODUCTION}

Fire blight caused by phytobacterium Erwinia amylovora (Burrill) (Winslow et al., 1920) is one of the most important diseases affecting rosaceous fruits including pear trees in many countries of the world. In Egypt, the disease is epidemic in some years, thus the economic importance has been considered (El-Helaly et al., 1964).

The common practice of the disease control worldwide is restricted to the use of formulated bactericide(s) chemicals, chemicals of biological origin as streptomycin sulphate, and biological control (Vanneste, 2011). The hazards of using formulated chemicals and streptomycin as successive treatments, either single or combined, for the disease control raised the scope of challenges regarding the environmental safety (Stockwell and Duffy, 2012). Therefor, the use of agricultural practices devoiding, as far as possible, the chemical usage for fire-blight control has been decidedly considered. Among these practices, the development of resistant rootstocks of pear, depending on tissue culture technique, was examined.

Through tissues culture, it is now possible to examine the selection of callus cultures, somaclonal variations, host-pathogen interactions, disease resistance and germplasm with enhanced disease resistance (Remotti et al., 1997). Selection for disease resistance in breeding fruit crops is an alternative to genetic engineering (Chandra et al., 2004; Chandra and Mishra, 2007). Phytotoxic metabolites of most pathogens have been reported to play a significant role in pathogenesis (Amusa et al., 1993) and these have been employed in screening crops for improved lines against disease resistance (Amusa, 1998 and 2000). The principle behind this approach is that the metabolites present in the culture filtrate serve as selection agent for evolving resistant lines. In vitro selection offers immense potential for quick and comprehensive generation of useful somaclones or 
mutants for resistance to various abiotic and biotic stresses and its potential application in fruit crops. Plants produced from tissue culture techniques may serve as excellent donor of the resistance gene(s) in the breeding program (Ramesh et al., 2010). The present study was conducted mainly to produce pear rootstocks resistance against fire blight disease and also to produce plants resistant to streptomycin-resistant isolates of E. amylovora.

\section{MATERIALS AND METHODS}

The investigations of the present study were achieved at the Tissue Culture and Germplasm Conservation Research Lab. of the H.R.I. Giza collaboration with the Plant Pathology Bacterial Laboratory. Plant Path. Inst., ARC, Egypt during 2012 and 2013 seasons.

\subsection{Isolation and identification of the pathogen}

Diseased pear flowers, leaves and fruitlets with typical symptoms of fire blight were collected from trees of El-Nubaria fields and used for isolation. The infected samples were washed in sterile water and pieces of the tissues were macerated in $2 \mathrm{ml}$ of sterile water in a petri-dish for $30 \mathrm{~min}$. A loopful of the resulting suspension was streaked onto the surface of the selective Miller and Schroth medium (MS) as highly selective for E. amylovora (Miller and Schroth, 1972). Then, they Were incubated at $28^{\circ} \mathrm{C}$. Single colonies developed after 2-3 days of incubation were transferred to King's B agar (KBA) slants.

Among tested isolates, the reference isolate of E. amylovora, (EA1) and two streptomycin resistant isolates (N0.40 ${ }^{\mathbf{R}}$ and No. $80^{\mathbf{R}}$ ) were kindly provided by the Plant Bacterial Disease Dept., Plant Path. Inst., ARC, Giza, Egypt (Shaheen, 2010).

\subsection{Pathogenicity test}

Small green immature pear fruitlets $(0.5 \mathrm{~m}$ in diam.) were surface sterilized by dipping in sodium hypochlorite solution $(0.5 \%)$ for $10 \mathrm{~min}$ then rinsed several times with sterile distilled water (SDW). These fruitlets were kept in sterilized plates after stabbing with a needle laden with $24 \mathrm{hrs}$ culture of the bacterium. Each plate contained four inoculated fruitlets in which high humidity was maintained with wet cotton and incubated at $28^{\circ} \mathrm{C}$ for $3-5$ days. Control pear fruitlets were inoculated with SDW. Inoculated fruitlets were macroscopically examined after 3-5 days for distinct symptoms and copious bacterial oozing (Schaad, 1980). Re-isolation was carried out from the infected fruitlets material.

The isolated bacteria were identified according to their morphological, cultural and biochemical characteristics (Krieg et al., 1994). This study was carried out at the Plant Pathology Bacterial Laboratory. Plant Path. Inst., ARC, Egypt.

\subsection{Plant Material}

Meristem tips selected from pear (Pyrus communis var. betulifolia) seedlings were disinfected by $70 \%$ ethanol for $10 \mathrm{~min}$. followed by dipping in $15 \%$ sodium hypochlorite for 15 min. and finally rinsed in sterile water 3 times.

\subsection{Preparation of the callus}

Explants were dissected into small pieces $(0.3$ $\mathrm{cm})$ and cultured on Murashige and Skoog medium (Murashige and Skoog, 1962), supplemented with $2.8 \mathrm{mg} / \mathrm{l}$ Myo-inositol +2.5 $\mathrm{mg} / \mathrm{l}$ thiamine $\mathrm{Hcl}+1 \mathrm{mg} / \mathrm{l} \mathrm{BAP}+2.5 \mathrm{mg} / \mathrm{l}$ 2,4-D . Calli formed. after three weeks. These calluses were cultured again on the same media mentioned before. Formed calli were infected by bacterial strain of E. amylovora.

\subsection{E. amylovora potentials to cause blackening on produced callus}

After six weeks, formed calli were injected with bacterial cell suspensions $\left(10^{8} \mathrm{cfu} / \mathrm{ml}\right)$ of the two highly virulent isolates (No. $2^{\mathrm{S}}$ and No. $4^{\mathrm{S}}$ ). Callus was carried out with two streptomycin resistant isolates (No.40 $\mathbf{R}^{\mathbf{R}}$ and $N o .80^{\mathbf{R}}$ ) of $E$. amylovora. The injection of the callus was preformed by syringe. The negative control was prepared by using callus inoculated with SDW. Three replicates (Jars) were used for each isolate. All jars of the inoculated callus were incubated at $25^{\circ} \mathrm{C}$ for 7 days. The effect on callus was measured by blackening of the cells of callus. This study was carried out under the conditions of the Tissue Culture Laboratory with cooperation of the Plant Pathology Bacterial Laboratory, Plant Path. Inst., ARC, Egypt.

\subsection{Regeneration of the plants from resistant calluses}

Resistant calli (without blackening) were kept for 3 weeks on full strength of MS media supplemented with $2.8 \mathrm{mg} / \mathrm{l}$ Myo-Inositol +2.5 $\mathrm{mg} / \mathrm{L}$ thiamine $\mathrm{Hcl}+30 \mathrm{~g} / \mathrm{l}$ sucrose $+7 \mathrm{~g} / \mathrm{l}$ agar + different concentrations of hormones as follow:

- $\mathrm{GA}_{3}(0.5 \mathrm{mg} / \mathrm{l})+2 \mathrm{ip}(1.5 \mathrm{mg} / \mathrm{l})+\mathrm{IAA}(1.5 \mathrm{mg} / \mathrm{l})$.

- 2ip $(1.5 \mathrm{mg} / \mathrm{l})+\mathrm{IAA}(1.5 \mathrm{mg} / \mathrm{l})$.

- $\mathrm{GA}_{3}(0.5 \mathrm{mg} / \mathrm{l})+\mathrm{IAA}(1.5 \mathrm{mg} / \mathrm{l})$.

- $\mathrm{GA}_{3}(1.5 \mathrm{mg} / \mathrm{l})+2 \mathrm{ip}(1.5 \mathrm{mg} / \mathrm{l})$.

Finally the media $\mathrm{pH}$ was adjusted to 5.6.

Regenerated plantlets were formed after 95 days on these media.

\subsection{Rooting induction}

Regenerated shoots were separated into individual shoots and transferred onto rooting medium (half strength MS media+ $2.8 \mathrm{mg} / \mathrm{l}$ Myo- 
Inositol $+2.5 \mathrm{mg} / \mathrm{L}$ thiamine $\mathrm{Hcl}+20 \mathrm{~g} / \mathrm{l}$ sucrose $+7 \mathrm{~g}$ agar/l, supplemented with different concentrations of hormones $(1.5 \mathrm{mg} / \mathrm{l}$ IBA+ $2 \mathrm{mg} / \mathrm{l} \mathrm{BAP})$ or $(1.5 \mathrm{mg} / \mathrm{l} \mathrm{IBA}+2 \mathrm{mg} / \mathrm{l} \mathrm{BAP}+1.5$ $\mathrm{mg} / \mathrm{l} \mathrm{IAA}$ ) and the media adjusted to $\mathrm{pH} 5.6$, then kept for another 4 weeks.

\subsection{Calculated parameters}

The number of survival callus, the number of regenerated plants, shoot length $(\mathrm{cm})$, the number of leaves, leaf area $\left(\mathrm{cm}^{2}\right)$, root length $(\mathrm{cm})$ and the number of roots were recorded.

\subsection{Acclimatization stage}

For acclimatization, the plants were transplanted into small plastic pots $(10 \mathrm{~cm} \times 20$ $\mathrm{cm}$ ) filled by a mixture of Peatmoss and sand 2:1 $(\mathrm{v} / \mathrm{v})$ in greenhouse. The number of acclimatized plants were recorded after 2 months.

2.10. Efficacy of bacterial isolates on acclimatized plants

After 10 weeks of acclimatization, the acclimatized plants were inoculated with the same isolates used before (No. $2^{\mathrm{S}}, 4^{\mathrm{S}}$ and $40^{\mathbf{R}}$ ). The two youngest actively growing leaves were cut with a scissors to produce a wound in the tip of the leaf, and then painting the wound with a paint brush dipped into the bacterial suspension $\left(10^{8} \mathrm{cfu} / \mathrm{ml}\right)$. The negative control was prepared by using leaves inoculated with SDW. For each treatment, five replicates (plants) were used for each isolate. Inoculated plants were incubated at $25^{\circ} \mathrm{C}$ (7 days) into plastic bags to examine the degree of necrosis and copious bacterial oozing (symptoms of fire blight). Every 2 days, the bags were opened to permit air exchange. This method can be used to evaluate plant susceptibility or resistance for $E$. amylovora (Ruz et al., 2008). The disease severity was calculated as the number of infected plants/ total number of inoculated plants X100.

\subsection{Statistical analysis}

Each treatment was performed in six jars containing five explants and each experiment was replicated three times. The data were subjected to analysis of variance by MSTAT - C (1990) computer statistical analysis program. LSD, test at the $5 \%$ level of significance $(\mathrm{p}=0.05)$.

\section{RESULTS AND DISCUSSION \\ 3.1. Isolation, identification and pathogenicity test for the pathogen}

Colonies of the bacterial isolates showed reddish - orange colored with deep orange in the centre on Miller and Schroth (MS) medium. The morphological and biochemical characteristics of the isolated bacteria (Table 1) indicated that, all the obtained isolates (four susceptible isolates and $\mathrm{EA}_{1}$ reference) were short rod, non-sporulated and gave negative results for gram staining, nitrate reduction, kovac 's oxidase test, indole formation, produce $\mathrm{H}_{2} \mathrm{~S}$ from cystein, growth at $36^{\circ} \mathrm{C}$. All isolates could liquefy gelatin, levan production from sucrose. On the other hand, all isolates could produce acid within 7 days from glucose, but acid was not produced from lactose.

For pathogenicity, all tested isolates were able to infect pear fruitlets after 4 days, but with different degree of severity and copious bacterial

Table (1): Morphological and biochemical characteristics of E. amylovora isolates.

\begin{tabular}{|l|c|c|c|c|c|}
\hline \multirow{2}{*}{\multicolumn{1}{c|}{ Characteristics }} & \multicolumn{5}{c|}{ Obtained isolates } \\
\cline { 2 - 6 } & $\mathbf{1}$ & $\mathbf{2}$ & $\mathbf{3}$ & $\mathbf{4}$ & EA $_{\mathbf{1}}$ \\
\hline Cell shape & SR & SR & SR & SR & SR \\
\hline Sporulation & - & - & - & - & - \\
\hline Gram staining & - & - & - & - & - \\
\hline Nitrate reduction & - & - & - & - & - \\
\hline Oxidase & - & - & - & - & - \\
\hline Indole formation & - & - & - & - & - \\
\hline $\mathrm{H}_{2}$ S production & - & - & - & - & - \\
\hline Gelatin liquefaction & + & + & + & + & + \\
\hline Growth at 36 ${ }^{\circ} \mathrm{C}$ & - & - & - & - & - \\
\hline Levan production & + & + & + & + & + \\
\hline Acid production from: & & & & & + \\
\hline Glucose & + & + & + & + & - \\
Lactose & - & - & - & - & + \\
\hline
\end{tabular}

$(+)$ : Positive reaction- Acid from sugars.

(SR) : Short rod.

$(-)$ : Negative reaction- no acid was produced from sugars. 
oozing, where isolates No.2 and No.4 gave blackening necrosis and copious oozing, isolate No.1 gave moderate oozing and necrosis compared with the reference isolate $\left(\mathrm{EA}_{1}\right)$ that gave blackening necrosis and copious oozing. Isolate No.3 gave weak, slight oozing and necrosis. Isolates No. $2 \& 4$ were taken to infect the calluses.

\section{2. $E$. amylovora potentials in causing} blackening on callus

Data in Table (2) showed that, there was a different degree in the resistance of callus, where some part of the callus did not show blackening (resistant) and contrary to the other that showed blackening at different degree (moderate resistance and highly susceptible) compared to the control which did not give blackening.

Table (2): Tentative determination on the effect of bacterial isolates on callus (after 7 days).

\begin{tabular}{|l|c|c|c|}
\hline Isolates & & \multicolumn{2}{|c|}{ Injection calluses } \\
\hline $2^{\mathrm{S}}$ & 1 & 2 & 3 \\
\hline $4^{\mathrm{S}}$ & - & +++ & - \\
\hline $80^{\mathrm{R}}$ & - & ++ & ++ \\
\hline $40^{\mathrm{R}}$ & ++ & +++ & - \\
\hline Control & - & + & + \\
\hline$-:$ No necrosis & - & - \\
$++:$ Moderate necrosis & ++ : Weak necrosis \\
$\mathrm{S}:$ Streptomycin sensitive isolates \\
$\mathrm{R}:$ Streptomycin resistant isolates
\end{tabular}

\subsection{Effect of different bacterial isolates on survival callus and regenerated plantlets}

It was clear that the survival of the callus was affected by the type of the bacterial isolate used (Fig.1 and 2). The highest number of callus survival (resistant) was obtained from calluses infected by isolate No. $40^{\mathrm{R}}$; whereas, the lowest number was gained from calluses infected by isolate No. $80^{\mathrm{R}}$. In this respect, Ramesh et al. (2010) stated that, somaclonal variation alone

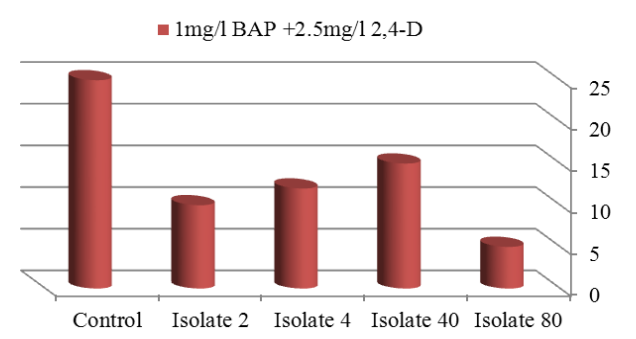

Fig.(1): Number of callus survival as affected by different isolates of bacterial strains. offers new possible sources of altered characters, including susceptibility and/ or resistance to pathogen.

The number of regenerated plantlets followed the same trend of callus survival with all of the tested bacterial isolates. However, no regenerated plantlets were obtained from calli resistant to isolate No.80 ${ }^{\mathrm{R}}$. Moreover, the number of regenerated plantlets was affected by the type of the used hormones. Four different hormonal combinations were used to develop regenerated plantlets from callus (Fig 3). It was clear that, $\mathrm{GA}_{\mathbf{3}}$ at $1.5 \mathrm{mg} / \mathrm{l}$ along with $2 \mathrm{ip}$ at $1.5 \mathrm{mg} / \mathrm{l}$ represented the highest significant number of regenerated plantlets. Meanwhile, hormonal combinations containing $2 \mathrm{ip}$ at $1.5 \mathrm{mg} / \mathrm{l}$ within IAA at $1.5 \mathrm{mg} / \mathrm{l}$ detected the lowest significant number of regenerated plantlets. No regenerated plantlets were gained with the combination of $\mathrm{GA}_{3}$ at $0.5 \mathrm{mg} / \mathrm{l}$ plus IAA at $1.5 \mathrm{mg} / \mathrm{l}$. It was observed that, when the concentration of $\mathrm{GA}_{3}$ was reduced to $0.5 \mathrm{mg} / \mathrm{L}$, the number of regenerated plantlets was decreased

\subsection{Effect of cytokinin on vegetative growth parameters}

The phenotype and vegetative growth characteristics were affected by bacterial isolate treatments and the used hormones (Table 3). Regarding the vegetative growth parameters, it almost recorded a high value with plants gained from callus resistant to isolates $N o .40^{\mathrm{R}}$ as compared to isolates No. $2^{\mathrm{S}}$ and No. $4^{\mathrm{S}}$. However, all of the tested bacterial isolates detected value lower than controls with all vegetative growth parameters. Shoot number was increased with BA at $2 \mathrm{mg} / \mathrm{l}$ for all of the tested treatments. TDZ hormone at $1 \mathrm{mg} / \mathrm{l}$ recorded the highest value of shoot length with isolate No. $2^{\mathrm{S}}$ only and decreased shoot length with the remaining isolates. Abd-El Rahman et al. (2007) evaluated the response of the shoots and quality of the shoots produced with 2 $\mathrm{mg} / \mathrm{l} \mathrm{BA}$ and chosen as the preferred treatment because it yielded the maximal number of shoots with the best quality and used the least amount of BA to produce the desired result. Moreover, Haw and Keng (2003) revealed that the aseptic axillary buds formed multiple shoots within five weeks when cultured on MS medium supplemented with $2.0 \mathrm{mg} / 1 \mathrm{~N} 6$-Benzyl adenine (BA).

A fluctuated effect was observed for the three hormonal combinations regarding the leaf number and no consistent trend was revealed. Moreover, no significant differences were observed for leaf area with the used hormone combinations for all of tested isolates and even with the control. 


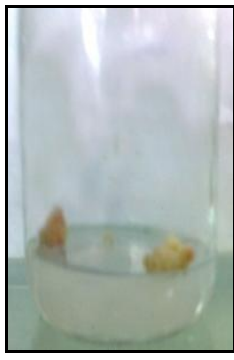

A

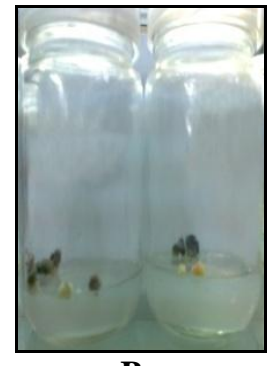

B

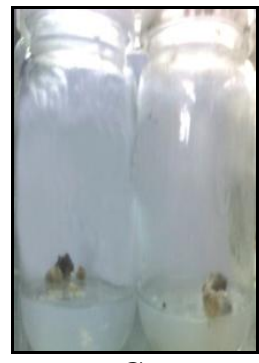

C

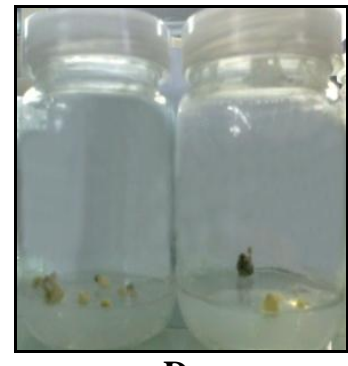

D

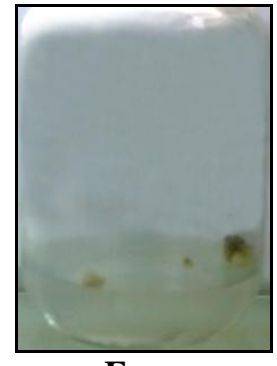

$\mathbf{E}$

Fig.(2): Resistant callus resulted from: control(A), infected with bacterial isolateNo. ${ }^{\mathrm{S}}(\mathrm{B})$, infected with bacterial isolate No. $4^{\mathrm{S}}(\mathrm{C})$, infected with bacterial isolate $\mathrm{No} 40^{\mathrm{R}}(\mathrm{D})$ and infected with bacterial isolate $\mathrm{No.}^{\mathrm{R} 0^{\mathrm{R}}}(\mathrm{E})$.

$=\mathrm{GA} 3(0.5 \mathrm{mg} / 1)+2 \mathrm{ip}(1.5 \mathrm{mg} / 1)+\mathrm{IA}$ $\mathrm{A}(1.5 \mathrm{mg} / 1)$

$2 \mathrm{ip}(1.5 \mathrm{mg} / 1)+\operatorname{IAA}(1.5 \mathrm{mg} / 1)$

$\mathrm{GA} 3(0.5 \mathrm{mg} / \mathrm{l})+\mathrm{IAA}(1.5 \mathrm{mg} / 1)$

GA3 $(1.5 \mathrm{mg} / 1)+2 \mathrm{ip}(1.5 \mathrm{mg} / 1)$

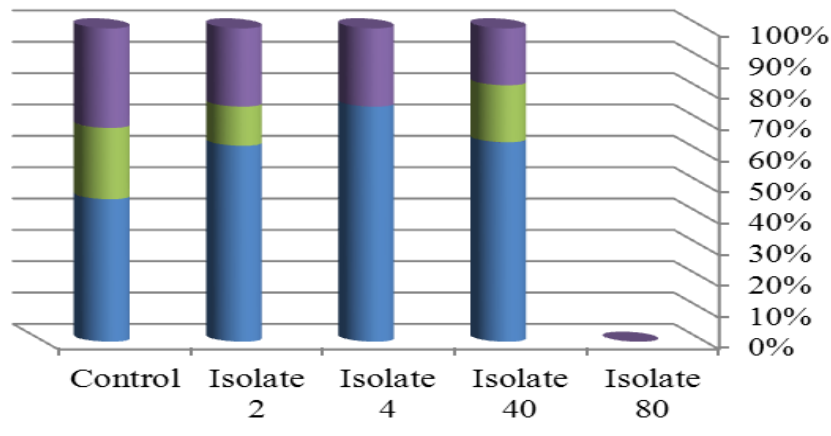

Fig. (3): Effect of different hormonal combinations on the number of regenerated plantlets.

\subsection{Rooting percentage as affected by hormonal type and its concentration}

Half strength of MS medium was used to induce root formation, rooting percentage was high when BAP $2 \mathrm{mg} / 1$ combined with IBA 1.5 $\mathrm{mg} / \mathrm{l}$ followed by IAA $1.5 \mathrm{mg} / \mathrm{l}+\mathrm{BAP} 2 \mathrm{mg} / \mathrm{l}$ and IBA $1.5 \mathrm{mg} / \mathrm{l}$. The average number of roots always was higher for the first hormone combination than the second one with significant variance for all of the tested isolates (Table 4). When IBA $(1.5 \mathrm{mg} / \mathrm{l})$ and BAP $(2 \mathrm{mg} / \mathrm{l})$ were used alone it gave the highest percentage of rooted plantlets comparing with IAA $1.5 \mathrm{mg} / \mathrm{l}+\mathrm{BAP} 2$ $\mathrm{mg} / \mathrm{l}+\mathrm{IBA} 1.5 \mathrm{mg} / \mathrm{l}$. Root length also recorded a high value with BAP $2 \mathrm{mg} / \mathrm{l}$ along with IBA 1.5 $\mathrm{mg} / \mathrm{l}$. Root length also revealed non significant effect for the tested bacterial isolate when compared with the control. Abd El-Rahman et al. (2007) demonstrated that IBA resulted in $100 \%$ rooting, however, a decline in rooting ability was obtained with NAA and poor rooting (10\%) in shoots harvested from the control (free auxin). Moreover, the highest number of roots per shoot of pear was 14 on MS medium supplemented with $2 \mathrm{mg} / \mathrm{l} \mathrm{IBA}$.

\subsection{Effect of bacterial isolates on acclimatized plants in green house}

Data in Table (5) and Fig. (4) indicated that plants derived from callus infected by the resistant isolate No. $40^{\mathbf{R}}$ were resistant to the same isolate after acclimatization, also, the plants derived from callus infected with streptomycin- sensitive isolate No. $4^{\mathrm{s}}$, gave a higher disease severity $(60 \%)$ than the corresponding percentage of plants obtained from callus infected with streptomycin- sensitive isolate (No. $2^{\mathbf{s}}$ ) with $40 \%$ compared with the control without bacteria.

This study clearly showed the differences between susceptibility and resistance cell line of infected callus via in vitro culture. Our data can be regarded as indicating the potential of a betulifolia rootstock to be infected by E. amylovora under laboratory conditions favorable for the disease. Moreover, the resulted accessions should be also tested for susceptibility when grafted by certain cultivars to ensure its resistance.

Apparently we could produce plants resistant to streptomycin- resistant isolates of $E$. amylovora, to avoid deleterious effect of streptomycin. In this regard, Mohamed et al. 


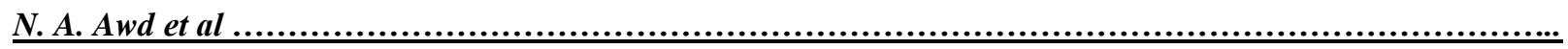

Table (3): Effect of cytokinin on vegetative growth parameters.

\begin{tabular}{|c|c|c|c|c|c|c|c|c|c|c|c|c|}
\hline \multirow[b]{2}{*}{$\begin{array}{l}\text { Bacterial } \\
\text { Isolate }\end{array}$} & \multicolumn{4}{|c|}{ BA (2mg/l) } & \multicolumn{4}{|c|}{ TDZ (1mg/l) } & \multicolumn{4}{|c|}{ BA (2mg/l) + TDZ (1mg/l) } \\
\hline & $\begin{array}{c}\text { Shoot } \\
\text { number }\end{array}$ & $\begin{array}{l}\text { Shoot } \\
\text { length }\end{array}$ & $\begin{array}{c}\text { Leaf } \\
\text { number }\end{array}$ & $\begin{array}{l}\text { Leaf } \\
\text { area }\end{array}$ & $\begin{array}{c}\text { Shoot } \\
\text { number }\end{array}$ & $\begin{array}{l}\text { Shoot } \\
\text { length }\end{array}$ & $\begin{array}{c}\text { Leaf } \\
\text { number }\end{array}$ & $\begin{array}{l}\text { Leaf } \\
\text { area }\end{array}$ & $\begin{array}{c}\text { Shoot } \\
\text { number }\end{array}$ & $\begin{array}{l}\text { Shoot } \\
\text { length }\end{array}$ & $\begin{array}{c}\text { Leaf } \\
\text { number }\end{array}$ & $\begin{array}{l}\text { Leaf } \\
\text { area }\end{array}$ \\
\hline Control & 6.31 & 9.40 & 5.67 & 5.62 & 4.50 & 7.33 & 4.32 & 4.11 & 3.87 & 6.50 & 6.22 & 4.41 \\
\hline Isolate $2^{\mathrm{s}}$ & 4.33 & 7.49 & 5.90 & 3.82 & 4.21 & 8.66 & 3.89 & 3.61 & 3.92 & 6.12 & 4.81 & 3.65 \\
\hline Isolate $4^{\mathrm{s}}$ & 6.11 & 8.32 & 4.00 & 4.20 & 5.45 & 7.35 & 5.71 & 3.42 & 2.28 & 6.11 & 3.33 & 4.53 \\
\hline Isolate $40^{\mathrm{R}}$ & 8.34 & 6.15 & 4.05 & 3.96 & 7.25 & 6.00 & 5.48 & 4.83 & 3.21 & 5.2 & 5.93 & 4.86 \\
\hline LSD at $5 \%$ & 1.10 & 0.43 & 0.69 & 0.41 & 3.21 & 2.98 & 3.56 & 2.51 & 289 & 3.70 & 2.67 & 2.88 \\
\hline
\end{tabular}

Table (4): Effect of auxin type on rooting percentage and root character.

\begin{tabular}{|l|c|c|c|c|c|c|}
\hline \multirow{2}{*}{ Bacterial Isolate } & \multicolumn{3}{|c|}{ IBA(1.5mg/l) + BAP (2mg/l) } & \multicolumn{2}{c|}{ IBA (1.5mg/l)+BAP (2mg/l) +IAA (1.5mg/l) } \\
\cline { 2 - 7 } & Rooting \% & Root number & Root length & Rooting \% & Root number & Root length \\
\hline Control & 95.90 & 5.33 & 5.72 & 92.49 & 5.41 & 4.26 \\
Isolate 2 & 87.5 & 6.66 & 6.82 & 83.51 & 5.12 & 5.41 \\
Isolate 4 $^{\mathrm{S}}$ & 82.11 & 7.35 & 5.21 & 82.81 & 4.58 & 4.30 \\
Isolate 40 & 92.45 & 5.00 & 6.49 & 83.21 & 3.23 & 5.93 \\
LSD at 5\% & 10.34 & 2.76 & 3.56 & 11.89 & 3.09 & 2.05 \\
\hline
\end{tabular}




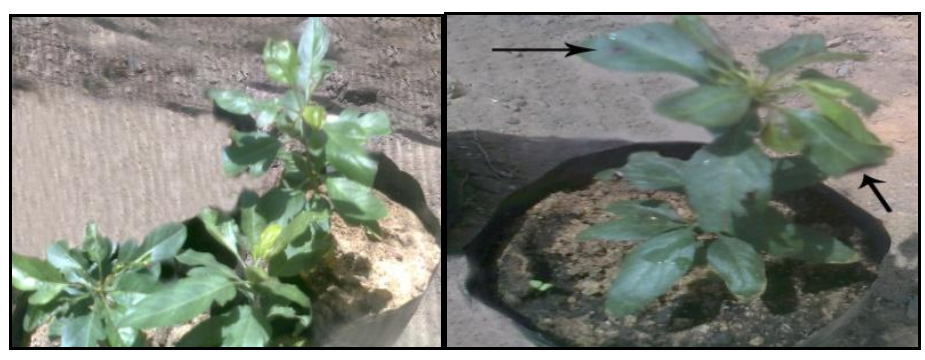

(A)
Infected plant

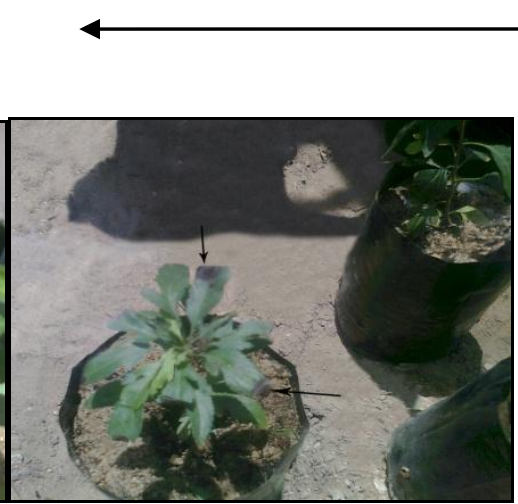

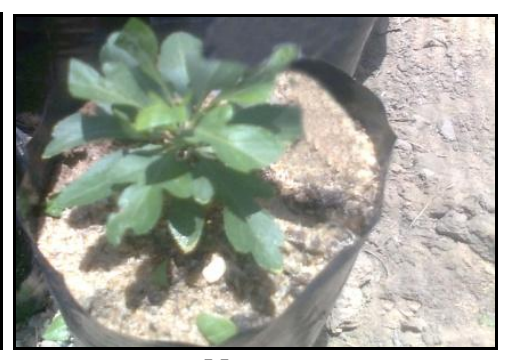

Non infected plant

(B)

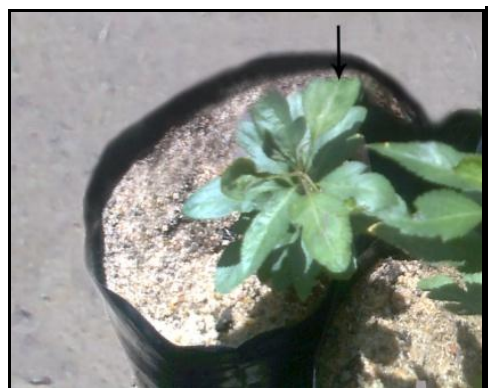

Non infected plant
Infected plant

$\rightarrow$

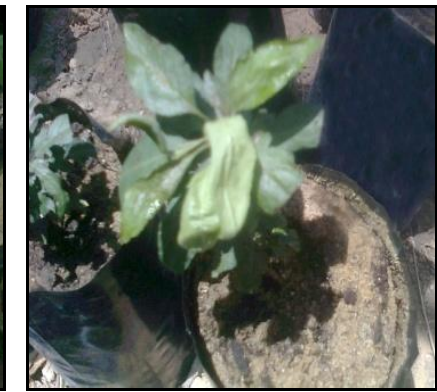

(D)

(C)

Fig.(4): Effect of bacterial isolates on the acclimatized plants in the green house: control(A), infected by bacterial isolate No. 2(B), infected by bacterial isolate No. 4(C) and bacterial isolate No. 40(D).

(2006) showed that rootstocks of pear plantlets tolerant or resistant against fire blight can be produced by tissue culture.

Table (5): Disease severity of fire blight on acclimatized plants in pot experiment.

\begin{tabular}{|c|c|}
\hline Bacterial isolates & Disease severity\% \\
\hline $\mathbf{2}^{\mathrm{S}}$ & $\mathbf{4 0}$ \\
\hline $\mathbf{4}^{\mathrm{S}}$ & $\mathbf{6 0}$ \\
\hline $\mathbf{4 0}$ & $\mathbf{0}$ \\
\hline Control $^{\mathrm{R}}$ & $\mathbf{0}$ \\
\hline
\end{tabular}

$\mathbf{S}:$ Streptomycin sensitive isolates

$\mathbf{R}$ : Streptomycin resistant isolates

\section{REFERENCES}

Abd El-Rahman M. F. A., Rizkalla Aida A. and Badr-Elden Awatef M. (2007). Micropropagation and biochemical genetic markers detection for drought and salt tolerance of pear rootstock. Australian J. Basic and Appli. Sci., 1(4): 625- 636.

Amusa N. A. (1998). Evaluation of cassava clones for resistance to anthracnose disease using phytotoxic manihotis. Trop. Agric. Res. 1: 116-120.
Amusa N. A. (2000). Screening cassava and yam cultivars for resistance to anthracnose using toxic metabolite of Colletotrichum species. Mycopathology. 150: 137-142.

Amusa N. A., Ikotun T. and Asiedu R. (1993). Extraction of phytotoxic substance from Colletotrichum gloeosporioides infected yam leaves. Int. J. Trop. Dis. 11: 207-211.

Chandra R. and Mishra M. (2007). Biotechnological interventions for improvement of guava (Pisidium guajava L.). Acta Hort., 735: 117-125.

Chandra R. A., Bajpai S., Gupta S. and Tiwari R.K. (2004). Embryogensis and plant regeneration from mesocarp of Pisidium guajava L. Indian J. Biotec., 3: 246-248.

El-Helaly A. F., Abo-El-Dahab M. K. and ElGoorani M. A. (1964). The occurrence of the fire blight disease of pear in Egypt. Phytopathol. Medit., 3: 156-163.

Haw A. B. and Keng C. L. (2003). Micropropagation of Spilanthes acmella L., a bio-insecticide plant, through proliferation of multiple shoots. J. Appl. Hort., 5(2): 65-68.

Krieg N. R., Sneath P. H. A., Staley J. T. and Williams S. T. (1994). Bergey's Manual of Systematic Bacteriology, $9^{\text {th }}$ Ed., Williams 
and Wilkins, Baltimore, USA., $1391 \mathrm{pp}$.

Miller T. D. and Schroth M. N. (1972). Monitoring the epiphytic population of Erwinia amylovora on pear with a selective medium. Phytopathol., 62: 1175 -1182 .

Mohamed F. G., Mohamed G. M., Nabawi A. A. and Bauomy, Mosheira K. (2006). Usage tissue culture technique for production of pear rootstock plants resistance to fire blight disease. The 2nd Conf. On Farm Integrated Pest Management, Fayoum, Egypt. 201-210

MSTAT- C. (1990). Microcomputer statistical program for experiment design and analysis. MSTAT / Michigan State University, Michigan, USA.

Murashige T. and Skoog F. (1962). A revised medium for rapid growth and bioassays with tobacco tissue culture. Physiologia Plantarum, 15: 473-497.

Ramesh C., Kamel, M., Anju B., Muthkumar M. and Kalim S. (2010). In vitro selection: A candidate approach for disease resistance breeding in fruit crops. Asian J. Pl. Sci., 9(8): 437-446.

Remotti P. C., Loffler H. J. M. and Vloten L. V.
(1997). Selection of cell-lines and regeneration of plants resistance to fusaric acid from Gladiolus x grandifolrus cv peter pears. Euphytica, 96: 237- 245.

Ruz L., Moragrega C. and Montesinos E. (2008). Evaluation of four whole-plant inoculation methods to analyze the pathogenicity of Erwinia amylovora under quarantine conditions. Int. Microbiol. 11:111-119.

Schaad N. W. (1980). Laboratory Guide for Identification of Plant Pathogenic Bacteria. The American Phytopathological Society. St. Paul, Minnesota, $72 \mathrm{pp}$.

Shaheen Hanan A. (2010). Studies on the efficacy of some chemicals and plant extracts in the control of plant pathogenic bacteria. Ph.D.Thesis, Fac. Agric., Cairo Univ., Egypt, 103pp.

Stockwell V. O. and Duffy B. (2012). Use of antibiotics in plant agriculture. Rev. Sci. Tech. Int. Epiz., 31(1): 199-210.

Vanneste J. L. (2011). Biological control agents of fire blight: successes and challenges. Acta Horticulturae, 896: 409 - 416.

Winslow C. E. A., Broadhurst J. and Buchanan R. E. (1920). The families and genera of the bacteria: Erwinia. J. Bact., 5: 209.

$$
\begin{aligned}
& \text { إنتاج أصول كمثري مقاومة للفحة النارية باستخدام طريقة زراعة الانسجة } \\
& \text { نهلة عبد الفتاح عوض - حنان علي شاهين* - رباب محمد عبد العزيز }
\end{aligned}
$$

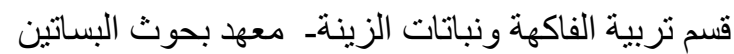

$$
\begin{aligned}
& \text { * قسم امر اض النباتات البكتريةــ معهد بحوثة امر اض النباتات ـ مركز البحوث البـاتين الزر اعيةـ الجيزة ـ مصر. }
\end{aligned}
$$

أستخدمت طريقة زراعة الانسجة لانتاج أصول نباتات كمثرى مقاومة لبكتريا Erwinia amylovora المبريا

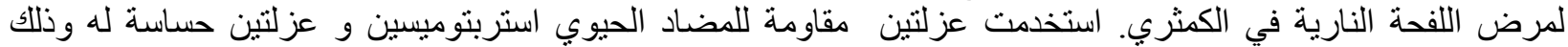

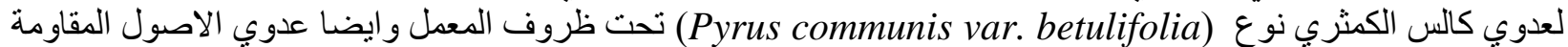

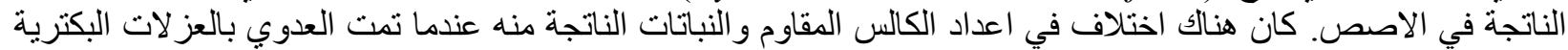

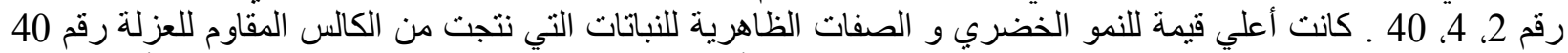

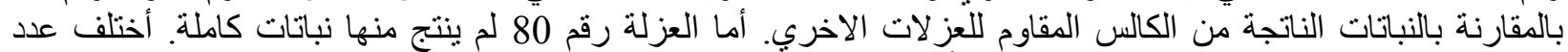

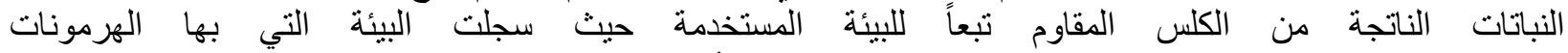
GA 3 (0.5mg/l)+IAA اعلى عدد للنباتات فى حين أن البيئة التي بها الهرمونات GA لم تعطى اي نباتات.

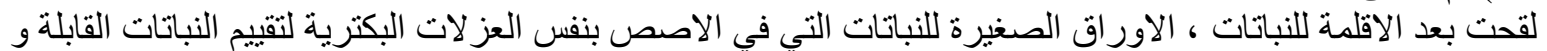

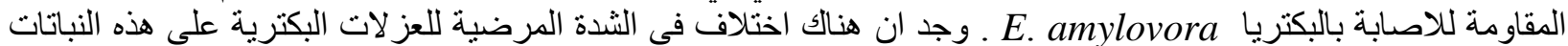

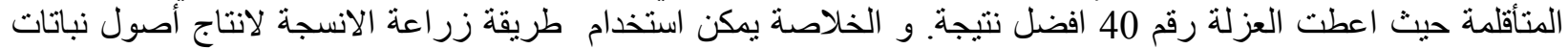

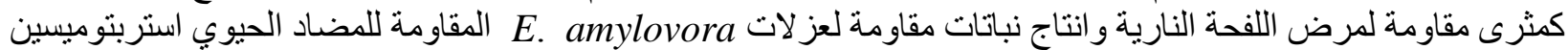

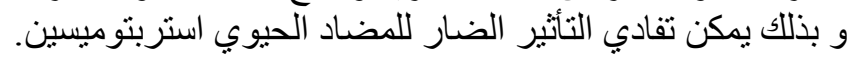

